\title{
The Role of Carbon Accountant in Corporate Carbon Management Systems: A Holistic Approach
}

\author{
Francis Chinedu Egbunike ${ }^{1 *}$ and Ochuko Benedict Emudainohwo ${ }^{2}$ \\ ${ }^{1}$ Nnamdi Azikiwe University, Department of Accountancy, Awka, Anambra State, \\ Nigeria \\ ${ }^{2}$ Delta State University, Department of Accounting and Finance, Abraka, Delta State, \\ Nigeria \\ *Correspondence to: Francis Chinedu Egbunike, Nnamdi Azikiwe University, \\ Department of Accountancy, PMB 5025, Awka, Anambra State, Nigeria \\ E-mail: chineduegbunike@rocketmail.com
}

\begin{abstract}
Carbon accounting consists of a combination of advanced cost allocation techniques such as activity-based management and life-cycle costing; that improve the identification and assignments of carbon-related expenses and overheads to such objects as products, services, customers and organizational processes. The study therefore sets out to find the role of carbon accountant in corporate management systems. Data used for this investigation were collected from primary and secondary sources. Primary data are first-hand information from respondents while Secondary data include textbook, Annual Reports and financial statements and internet facilities. The study employed descriptive survey and ex-post facto research design and the formulated hypotheses were tested by use of T-Test and OLS Regression. Based on the analysis and the hypothesis tested, it showed that there is a statistically significant relationship between carbon accounting and corporate performance of selected quoted Manufacturing Companies and based on this findings, it was recommended amongst others that, adaptation to conditions that include long-term changing dynamics of the natural environment should be encouraged and the focus of finance and accounting system should not only cover short-term outcomes and management of short-term costing, reporting and disclosure but also long-term climate risks.
\end{abstract}

Keywords: accountant, accounting, carbon, carbon accounting, manufacturing, Nigeria Stock Exchange.

Article info: Received 7 September 2017; revised 30 October 2017; accepted 29 November 2017

Recommended citation: Egbunike, F. C. \& Emudainohwo, O. B. (2017). The Role of Carbon Accountant in Corporate Carbon Management Systems: A Holistic Approach. Indonesian Journal of Sustainability Accounting and Management, 1(2), 90-104.

DOI: 10.28992/ijsam.v1i2.34

\section{Introduction}

There is growing unequivocal scientific evidence on the effects of human activity in general, and of Green House Gas (GHG) emissions in particular, on global warming that would worsen the already deteriorating ecological environment (IPCC, 2012); (Gunardi et al., 2016); (Rokhmawati et al., 2017). The 5th Assessment Report of the IPCC clearly stated that human interference with the climate system is occurring, and climate change poses severe risks for human and natural systems. The atmosphere and ocean have markedly warmed since the 1950s, the amounts of ice and snow have diminished, sea level has risen, and the concentrations of 
greenhouse gases have increased (IPCC, 2014); (Rokhmawati \& Gunardi, 2017). The negative impact of climate change on economy, social activities and people's health has already been emerging and the trend toward a low carbon economy has been beginning. Evidence points to the need to respond to the threats posed by climate change across businesses, industry and society (Linnenluecke \& Griffiths, 2010); (Surminski, 2013), and to adapt to those changes that will occur even if GHG emissions were stopped immediately (Linnenluecke et al., 2015).

Corporate carbon reduction initiatives and emissions reporting have expanded rapidly across firms, particularly as a response to institutional demands and value creation considerations. Regulatory and marketdriven changes are expected to have a major impact across a wide variety of industries (Tang \& Luo, 2014). The Kyoto Protocol was the original international regulatory response to global warming, under which more than 150 countries agreed to strive to decrease carbon dioxide (CO2) emissions (Ratnatunga \& Balachandran, 2009).

Aside from mandatory compliance, firms need to cope with rising investor demands for transparent and credible exposure to carbon levels and associated abatement costs (PricewaterhouseCoopers, 2009) and incorporate the assets, liabilities and risks associated with managing GHG emissions into traditional accounting, governance and control mechanisms (CIMA, 2010); (Hartmann et al., 2013). The carbon footprint concept has emerged to measure the impact (measured in $\mathrm{CO}_{2}$-equivalent) that a product, service or organization has on climate change (Finkbeiner, 2009); (Boguski, 2010); (Munasinghe, 2010).

Interest of accounting scholars on carbon emission and climate change initiatives is traceable to the discipline's longstanding interest in environmental reporting (Stechemesser \& Guenther, 2012). Climate change and the need to reduce GHG emissions is an extremely broad issue, touching almost all aspects of human life and values (Hoffman, 2011a); (Hoffman, 2011b), and requires that millions of individuals and organizations change their production procedure, consumption patterns and life style (Levy \& Egan, 2003); (Giddens, 2009). A few of the recommended carbon-reduction methods for business including changing light bulbs to low emission, switching off lights at quitting time, letting employees work close to home, and buying green power. A report by the Business Roundtable on Climate Change in Australia found that early action by companies to reduce $\mathrm{CO}_{2}$ emissions would add the equivalent of US\$1.8 trillion to gross domestic product (GDP) by 2050 and create more than 250,000 jobs (Weekes, 2007). To achieve this goal will require the efforts of the entire society, and accountants and auditors are expected to position themselves as managers of carbon control and implementation of climate change strategy (Lovell \& MacKenzie, 2011). Against this backdrop, this study investigates the role of carbon accountant in corporate carbon management systems.

Despite scientific warnings that climate change will have a significant impact on climate-exposed sectors such as water, agriculture, forestry, health and tourism (Hoffmann et al., 2009); (IPCC, 2012); (Linnenluecke et al, 2013), the corporate world has been slow to react, possibly due to lack of legislative guidance and formal changes to risk assessment, governance and disclosure requirements (Linnenluecke et al., 2015). Though, there is anecdotal evidence that suggests an increasing effort to incorporate carbon accounting into traditional decision and reporting processes (Hartmann et al., 2013), research with a carbon accounting focus is lacking. Corporate practice with collecting, managing and communicating corporate carbon related information is under researched (Kolk et al., 2008); (Hopwood, 2009); (Lohmann, 2009).

Studies have addressed the impact of global warming, carbon market and carbon regulations on corporate accounting practices (IETA, 2007); (Bebbington \& Larrinaga-González, 2008); (Cook, 2009); (CIMA, 2010); (Hartmann et al., 2013). Authors address issues such as the market effects of carbon emissions (Chapple et al., 2013); (Matsumura et al., 2014); (Romi, 2014), carbon assurance and auditing (Simnett et al., 2009); (Olson, 2010); (McKinnon, 2010), carbon cost accounting and carbon management accounting (Ratnatunga, 2007); (Ratnatunga, 2008); (Ratnatunga \& Balachandran, 2009); (Ratnatunga et al., 2011), carbon disclosure (Reid \& Toffel, 2009), etc. in a study by He et al. (2013), they observed that voluntary carbon disclosure is a 
rational choice that firms make to reduce the pressure exerted by legitimacy threats and to lower the cost of capital.

Previously, companies focused on adapting to short-term changing business conditions (including technological and legislative changes and changes in competitors and market demand), because finance and accounting systems are set up to focus on short-term outcomes and the management of short-term costing, reporting and disclosure, rather than on longer-term climate risks (Linnenluecke et al., 2015). As a result, considerably lesser attention been paid to adaptation to conditions that include long-term changing dynamics of the natural environment (Linnenluecke et al., 2013).

There is currently, scarcity of studies on the concept of carbon accounting in developing countries. More so there is a dearth of knowledge (Ratnatunga \& Balachandran, 2009) and scant evidence on efforts required and expended by accountants in this regard (Hartmann et al., 2013). As noted by Young (2010), GHG accounting is a huge challenge to accountants and accounting academics. Accountants have viewed their role as largely technical and nonstrategic (Lovell \& MacKenzie, 2011). Although attention directed to carbon issues in companies is on the increase, the amount of actual research conducted on information management practices in regard to carbon issues in companies to date remains limited (Okereke, 2007); (Jeswani et al., 2008). They study by (Matsumura et al., 2014) indicate that the markets penalize firms for their carbon emissions, but a further penalty is imposed on firms that do not disclose emissions information. This study is therefore set out to examine the role carbon accountants play in a corporate carbon management system.

The main objective of this study is to examine the role of carbon accountants play in a corporate carbon management system. The specific objectives of the study are to: 1) examine the awareness and extent of disclosure of carbon related information by manufacturing firms, 2) identify the role of accountants in settingup a corporate carbon management system in manufacturing firms, and 3) investigate the relationship between corporate carbon emissions and disclosure and corporate financial performance of manufacturing firms.

This study would be beneficial to: 1) Accountants: Accountants are key providers of information for decision-support in organizations; creating carbon information by means of accounting techniques and systems enables managers to gain a relative advantage in performing their managerial tasks and attaining the corporate objectives (Zvezdov \& Schaltegger, 2015). This study therefore highlights the role accountants need to play in this climate change era by considering measurements and strategies outside of conventional paradigms. 2) Businesses: Companies will increasingly and inevitably have to address climate change adaptation as an integral aspect of their business strategy and risk management (West \& Brereton, 2013). Because failure to manage the impacts of climate change can expose organizations to considerable risk: infrastructure and supply chains are adversely impacted due to climate and weather extremes with resulting financial impacts, business models and their limits are exposed (e.g. insurance companies and investment funds facing changing risk profiles), and reputational, legal and regulatory obligations arise (Linnenluecke et al., 2015). The findings therefore would be of interest to corporate top management who are interested in improving corporate carbon emission reduction, reporting and management strategy. More so, this study contributes to the understanding of how social concerns for climate change affect corporate financial performance. 3) Contribution to Literature: This study also contributes to sustainability literature, with a particular focus on corporate carbon accounting and disclosure by providing an overview of the process.

This study focuses on Carbon Accountants and their role in Corporate Carbon Management Systems in Nigeria. The study focuses on manufacturing companies, with a particular emphasis on Brewery and Beverage firms quoted on the Nigerian Stock Exchange (NSE) in Nigeria. The study covers a period of six years, from 20112016 financial year. The Carbon Accounting considered in this study are Community involvement, Research and Development, and other environmental and social disclosures as seen in the study. 


\section{Methods}

The focus of this study is on manufacturing companies listed on the Nigerian Stock Exchange (NSE). Manufacturing sector was chosen because it remains the most powerful engine for economic structure of countries (Jide, 2010). The quoted manufacturing companies are classified under several sectors, such as: Agriculture; Conglomerates; Construction/Real Estates; Consumer goods; ICT, and Industrial Goods. The selected companies are shown in Table 1.

Table 1 List of Selected Companies for the Study

\begin{tabular}{llll}
\hline A. G. Leventis & Dangote Sugar & Flour Mills of Nigeria & Nestle Nig Plc. \\
Ashaka Cem & Transcorp & GSK & Gigerian Breweries \\
Beta Glass & Arbico Plc & Guinness Nigeria Plc & SCOA \\
Cadbury Nigeria Plc & Berger Paints Nig Plc & Honeywell Flour Mills & UACN \\
CAP Plc & Pz Cussons & Julius Berger & Vitafoam \\
Chams & Champion Breweries & John Holt & Unilever Nig Plc \\
Chellarams Plc & Dangote Flour Mills & Livestock Feeds & Union Dicon Salt \\
Dangote Cement & First Aluminium Nig Plc. & Neimeth Int. Pharm. & 7-Up Bottling Coy. Plc. \\
Nasco Plc. & UTC Nig. Plc. & International Brew. Plc. & Nig. Enamelware Plc. \\
Ps Mandrides Plc. & Premier Paints Plc. & May and Baker Nig. Plc. & Multi-Trex Intgrt. Prdt. \\
\hline
\end{tabular}

Source: NSE Fact Book (2016)

Dependent variable

Return on Equity (ROE): this is a profitability ratio, measured as net profit/equity. The return on equity ratio or ROE is a profitability ratio that measures the ability of a firm to generate profits from its shareholders' investments in the company.

Independent variables

Environmental and Social Disclosure (ESD): In measuring the corporate environmental disclosure, the study employed content analysis technique. This is a research technique for the objective, systematic and qualitative description of the manifest content of communication. It is clearly defined by as a method of coding the text or the content of a piece of writing into various groups or categories based on selected criteria. Smith (2003) describes content analysis as a technique employed to derive meaningful inferences from texts in a document based on a predetermined set of criteria. That content analysis is rigorously developed, widely used and a very useful method of measuring environmental disclosure is well documented in the literature (Beck et al., 2010).

Control Variable

Control variables are related to the target variables though, are not primary variable of interest the inclusion of a control variable(s) is meant to remove its (their) effect(s) from the study's model. This study has 
added firm size as a control variable. Firm Size (FMS): Firm size is proxy with the logarithm of the Total Assets of the company for the financial year.

The data for the study were derived from primary and secondary sources; the primary data is derived from a structured questionnaire (see Appendix). The secondary data is obtained from annual financial statements of the selected companies.

A mean of 3.0 was used as decision thresh-hold in answering the research questions while the Sample Mean T-test was use in testing the formulated hypothesis. For the secondary data, the Ordinary Least-Squares (OLS) regression model was employed. It is a generalized linear modelling technique that may be used to model a single response variable which has been recorded on at least an interval scale. The technique may be applied to single or multiple explanatory variables and also categorical explanatory variables that have been appropriately coded (Hutcheson, 2011).

TESD $=(C I, E H \& S, C G, R \& D, O R E I)$

Where:

$\mathrm{Cl}=$ Community Involvement

EH\&S = Employee Health and Safety

$\mathrm{CG}=$ Corporate Governance

R\&D = Research and Development

OREI = Other Related Environmental Information

$\operatorname{ROE}(t)=a+\operatorname{TESD}(t)+F M S(t)+\mu$

Where:

ROE = Return on Equity

TESD = Total Environmental and social disclosure

FMS $=$ Firm Size

a $=$ Constant

$\mu \quad=$ error term, technically known as the stochastic disturbance or stochastic error term.

\section{Results and Discussion}

Table 2 shows that 29 respondents are females (i.e. 33.7\%), while 51 persons were males (i.e. 59.3\%). Table 3 showed that 20 respondents (i.e. 23.3\%) have between 0 to 5 years in service, 3 respondents (i.e. 3.5\%) have 6 to 10 years in service, 5 respondents (i.e. $5.8 \%$ ) have 11 to 15 years in service while 52 respondents (i.e. 60.5\%) have 16 years in service and above. This is an indication that a good percentage of respondents have stayed long on the job making easy to give a valid opinion on the subject matter. Table 4 shows that 45 respondents (i.e. 52.3\%) are in the mid-level management while 35 respondents (40.7\%) are senior managers.

Cronbach's alpha was employed in checking for reliability of the instrument, section B showed a value of 0.764 (see Table 5) and section C showed $\alpha$ value of 0.703 (see Table 6), both were greater than a generally accepted threshold of 0.70 . Thus, the measurement is reliable.

The Cronbach's alpha on the test of measurement reliability scale for role played by accountants in setting-up a corporate carbon management system in manufacturing firms showed an alpha level of 0.703 which is above the generally accepted threshold of 0.70 . Thus, the measurement is reliable. 
Table 2 Gender of Participants

\begin{tabular}{lccccc}
\hline & & Frequency & Percent & Valid Percent & Cumulative Percent \\
\hline Valid & Female & 29 & 33.7 & 36.3 & 36.3 \\
& Male & 51 & 59.3 & 63.7 & 100.0 \\
& Total & 80 & 93.0 & 100.0 & \\
Missing & System & 6 & 7.0 & & \\
Total & & 86 & 100.0 & & \\
\hline
\end{tabular}

Table 3 Years of Work Experience

\begin{tabular}{llcccc}
\hline & & Frequency & Percent & Valid Percent & Cumulative Percent \\
\hline Valid & $0-5$ & 20 & 23.3 & 25.0 & 25.0 \\
& $6-10$ & 3 & 3.5 & 3.8 & 28.7 \\
& $11-15$ & 5 & 5.8 & 6.3 & 35.0 \\
& 16-Above & 52 & 60.5 & 65.0 & 100.0 \\
& Total & 80 & 93.0 & 100.0 & \\
Missing & System & 6 & 7.0 & & \\
Total & & 86 & 100.0 & & \\
\hline
\end{tabular}

Table 4 Management Level of Participants

\begin{tabular}{llcccc}
\hline & & Frequency & Percent & Valid Percent & $\begin{array}{c}\text { Cumulative } \\
\text { Percent }\end{array}$ \\
\hline Valid & Staff Management & 45 & 52.3 & 56.3 & 56.3 \\
& Top Level (Line) Management & 35 & 40.7 & 43.8 & 100.0 \\
& Total & 80 & 93.0 & 100.0 & \\
\multirow{2}{*}{ Missing } & System & 6 & 7.0 & \\
Total & & 86 & 100.0 & \\
\hline
\end{tabular}

Table 7 showed the acceptance remark for all statements in response to investigative questions on the extent of manufacturing firm's awareness and disclose of carbon related information and a grand mean of 4.99 which is above the decision threshold of 3.0. Table 8 showed the t-test result to determine manufacturing firm's awareness and disclosure of carbon related information. Our analysis revealed a statistically significant result as shown in the above were $(t=395, N=80$ and $p=0.000)$ thus we reject the null hypotheses and conclude that Manufacturing firms are aware and disclose carbon related information. 
Table 5 Cronbach Alpha Values for Section B of Structured Questionnaire

\begin{tabular}{cc}
\hline Cronbach's Alpha & N of Items \\
\hline 0.764 & 5 \\
\hline
\end{tabular}

Table 6 Cronbach alpha values for section C of structured questionnaire

\begin{tabular}{cc}
\hline Cronbach's Alpha & N of Items \\
\hline 0.703 & 5 \\
\hline
\end{tabular}

Table 9 showed the acceptance remark for all statements in response to investigative questions on the role played by accountants in setting-up a corporate carbon management system in manufacturing firms and a grand mean of 4.954 which is above the decision threshold of 3.0. Table 10 showed the t-test result to determine the role accountants play in setting-up a corporate carbon management system in manufacturing firms. Our analysis revealed a statistically significant result as shown in the above were $(t=229.827,280.330$, $119.940,229.827$ and 229.827 for investigative questions 6 to $10 . \mathrm{N}=80$ and $\mathrm{p}=0.000$ ) thus we reject the null hypotheses and conclude that Accountants play a role in setting-up a corporate carbon management system in manufacturing firms.

The results (Table 11) suggest that TESD have strong significant positive relationship with the ROE at 5\% levels of significance indicating that any increase in the unit values of TESD will result to a corresponding increase in unit value of ROE. Finally, from Table 12, result revealed that there's a statistically significant Fstatistic of 11.288 (also revealing from our ANOVA table is a p-value $=0.000$, that is, $p$-value $<0.05$ ). The coefficients table, (see Table 13), showed that we reject the null hypotheses and conclude that there is a relationship between corporate carbon emissions and disclosure and corporate financial performance of manufacturing firms.

Table 7 Descriptive Statistics for Hypotheses 1

\begin{tabular}{|c|c|c|c|c|}
\hline & $\mathrm{N}$ & Mean & $\begin{array}{l}\text { Std. } \\
\text { Deviation }\end{array}$ & Remark \\
\hline $\begin{array}{l}\text { There is a global mandatory compliance on Carbon Management System to ease } \\
\text { the effect of climate change }\end{array}$ & 80 & 4.99 & 0.112 & Accept \\
\hline $\begin{array}{l}\text { My firm has totally complied to this mandate and promotes disclosure of carbon } \\
\text { emission and setting up of carbon management system }\end{array}$ & 80 & 4.99 & 0.112 & Accept \\
\hline $\begin{array}{l}\text { Carbon Accounting as a climate-change issues has been fully incorporated into } \\
\text { accounting and reporting. }\end{array}$ & 80 & 4.99 & 0.112 & Accept \\
\hline $\begin{array}{l}\text { Carbon related information have received attention to research and } \\
\text { development in my company }\end{array}$ & 80 & 4.99 & 0.112 & Accept \\
\hline $\begin{array}{l}\text { The Board of Directors has taken carbon disclosure as an integral part of my } \\
\text { company's Annual report }\end{array}$ & 80 & 4.99 & 0.112 & Accept \\
\hline
\end{tabular}


Table 8 One-Sample Test

\begin{tabular}{|c|c|c|c|c|c|c|}
\hline & \multicolumn{6}{|c|}{ Test Value $=0.05$} \\
\hline & \multirow[t]{2}{*}{$\mathrm{t}$} & \multirow[t]{2}{*}{$d f$} & \multirow[t]{2}{*}{$\begin{array}{l}\text { Sig. (2- } \\
\text { tailed) }\end{array}$} & \multirow[t]{2}{*}{$\begin{array}{c}\text { Mean } \\
\text { Difference }\end{array}$} & \multicolumn{2}{|c|}{$\begin{array}{l}95 \% \text { Confidence } \\
\text { Interval of the } \\
\text { Difference }\end{array}$} \\
\hline & & & & & Lower & Upper \\
\hline $\begin{array}{l}\text { There is a global mandatory compliance on Carbon } \\
\text { Management System to ease the effect of climate } \\
\text { change }\end{array}$ & 395.000 & 79 & 0.000 & 4.938 & 4.91 & 4.96 \\
\hline $\begin{array}{l}\text { My firm has totally complied to this mandate and } \\
\text { promotes disclosure of carbon emission and } \\
\text { setting up of carbon management system }\end{array}$ & 395.000 & 79 & 0.000 & 4.938 & $4 \cdot 91$ & 4.96 \\
\hline $\begin{array}{l}\text { Carbon Accounting as a climate-change issues has } \\
\text { been fully incorporated into accounting and } \\
\text { reporting. }\end{array}$ & 395.000 & 79 & 0.000 & 4.938 & 4.91 & 4.96 \\
\hline $\begin{array}{l}\text { Carbon related information have received } \\
\text { attention to research and development in my } \\
\text { company }\end{array}$ & 395.000 & 79 & 0.000 & 4.938 & $4 \cdot 91$ & 4.96 \\
\hline $\begin{array}{l}\text { The Board of Directors has taken carbon disclosure } \\
\text { as an integral part of my company's Annual report }\end{array}$ & 395.000 & 79 & 0.000 & 4.938 & 4.91 & 4.96 \\
\hline
\end{tabular}

Table 9 Descriptive Statistics for Hypotheses 2

\begin{tabular}{|c|c|c|c|c|}
\hline & $\mathrm{N}$ & Mean & $\begin{array}{c}\text { Std. } \\
\text { Deviation }\end{array}$ & Remark \\
\hline $\begin{array}{l}\text { Accountants uses Carbon Disclosure Project reports to examine empirically the } \\
\text { implementation of systems by firms and evaluate firms true carbon performance }\end{array}$ & 80 & 4.96 & 0.191 & Accept \\
\hline $\begin{array}{l}\text { An objectives of carbon accounting is to assist managers to formalize climate } \\
\text { change strategy }\end{array}$ & 80 & 4.98 & 0.157 & Accept \\
\hline $\begin{array}{l}\text { Carbon Management System brings about environmental effectiveness and } \\
\text { economic efficiency }\end{array}$ & 80 & 4.91 & 0.363 & Accept \\
\hline $\begin{array}{l}\text { Firms with higher quality Carbon Management System have achieved better } \\
\text { carbon mitigation. }\end{array}$ & 80 & 4.96 & 0.191 & Accept \\
\hline $\begin{array}{l}\text { Better performance in carbon management can lead to both tangible and } \\
\text { intangible outcomes, such as lessen the financial burden and even bring profit for } \\
\text { the company that does well }\end{array}$ & 80 & 4.96 & 0.191 & Accept \\
\hline
\end{tabular}

This work examined the role of carbon accounting in corporate carbon management system, and focused on 6 years period from 2011-2016. The first hypothesis which measured the extent of manufacturing firm's awareness and disclosure of carbon related information showed a strong support for the hypothesis. Respondents from most of the sampled firms showed that the firm has totally complied and promotes disclosure of carbon emission and setting up of carbon management system. This could be attributed to strong board support, as the respondents showed that Board of Directors took carbon disclosure as an integral part of my company's Annual report. Considering the problems that threaten the sustainability of the environment, companies need to be aware of the impact of their activities on the environment (Khoiruman \& Haryanto, 2017). 
Table 10 One-Sample Test

\begin{tabular}{|c|c|c|c|c|c|c|}
\hline & \multicolumn{6}{|c|}{ Test Value $=0.05$} \\
\hline & \multirow[t]{2}{*}{$\mathrm{t}$} & \multirow[t]{2}{*}{ Df } & \multirow[t]{2}{*}{$\begin{array}{l}\text { Sig. (2- } \\
\text { tailed) }\end{array}$} & \multirow[t]{2}{*}{$\begin{array}{c}\text { Mean } \\
\text { Difference }\end{array}$} & \multicolumn{2}{|c|}{$\begin{array}{l}95 \% \text { Confidence } \\
\text { Interval of the } \\
\text { Difference }\end{array}$} \\
\hline & & & & & Lower & Upper \\
\hline $\begin{array}{l}\text { Accountants uses Carbon Disclosure Project } \\
\text { reports to examine empirically the } \\
\text { implementation of systems by firms and } \\
\text { evaluate firms true carbon performance }\end{array}$ & 229.827 & 79 & 0.000 & 4.913 & 4.87 & 4.96 \\
\hline $\begin{array}{l}\text { An objectives of carbon accounting is to assist } \\
\text { managers to formalize climate change } \\
\text { strategy }\end{array}$ & 280.380 & 79 & 0.000 & 4.925 & 4.89 & 4.96 \\
\hline $\begin{array}{l}\text { Carbon Management System brings about } \\
\text { environmental effectiveness and economic } \\
\text { efficiency }\end{array}$ & $119 \cdot 940$ & 79 & 0.000 & 4.863 & 4.78 & $4 \cdot 94$ \\
\hline $\begin{array}{l}\text { Firms with higher quality Carbon Management } \\
\text { System have achieved better carbon } \\
\text { mitigation. }\end{array}$ & 229.827 & 79 & 0.000 & $4 \cdot 913$ & 4.87 & 4.96 \\
\hline $\begin{array}{l}\text { Better performance in carbon management } \\
\text { can lead to both tangible and intangible } \\
\text { outcomes, such as lessen the financial burden } \\
\text { and even bring profit for the company that } \\
\text { does well }\end{array}$ & 229.827 & 79 & 0.000 & $4 \cdot 913$ & 4.87 & 4.96 \\
\hline
\end{tabular}

Table 11 Model Summary

\begin{tabular}{ccccc}
\hline Model & R & R Square & Adjusted R Square & Std. Error of the Estimate \\
\hline 1 & $0.308^{\mathrm{a}}$ & 0.095 & 0.087 & .992538147353655
\end{tabular}

a. Predictors: (Constant), FMS, Total

(ESD)

Table 12 ANOVA

\begin{tabular}{|c|c|c|c|c|c|c|}
\hline \multicolumn{2}{|c|}{ Model } & \multirow{2}{*}{$\begin{array}{c}\text { Sum of Squares } \\
22.240\end{array}$} & \multirow{2}{*}{$\frac{\mathrm{df}}{2}$} & \multirow{2}{*}{$\begin{array}{c}\text { Mean Square } \\
11.120\end{array}$} & \multirow{2}{*}{$\frac{F}{11.288}$} & \multirow{2}{*}{$\frac{\text { Sig. }}{0.000^{b}}$} \\
\hline 1 & Regression & & & & & \\
\hline & Residual & 211.803 & 215 & 0.985 & & \\
\hline & Total & 234.043 & 217 & & & \\
\hline
\end{tabular}

a. Dependent Variable: ROE

b. Predictors: (Constant), FMS, Total

(ESD) 
Table 13 Coefficients

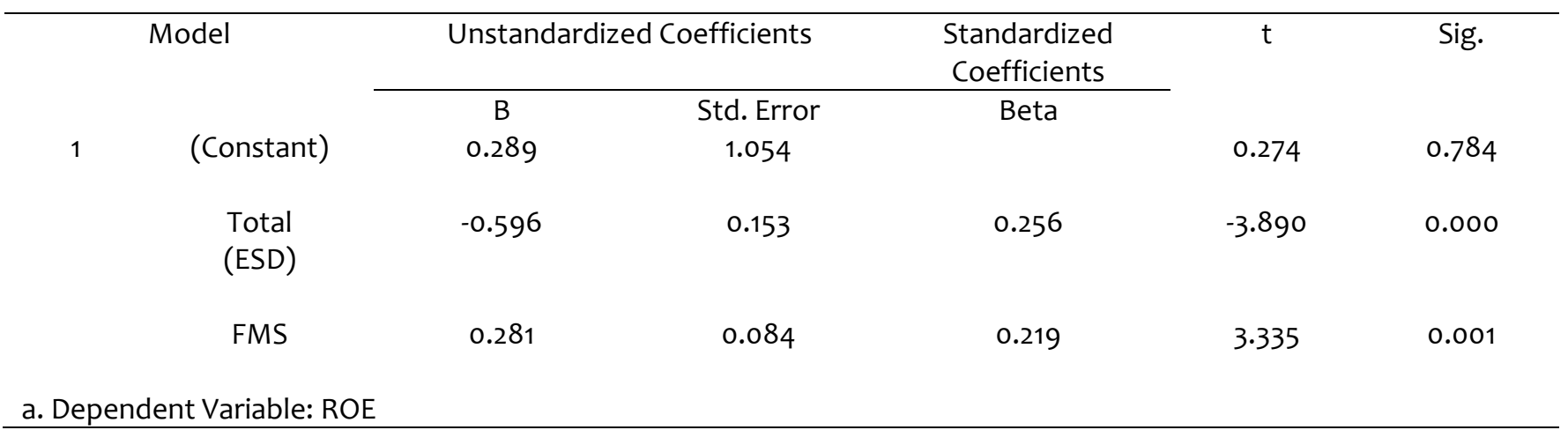

The second hypothesis which identified the role of accountants in setting-up a corporate carbon management system in manufacturing firms found that accountants play a role in setting up a corporate carbon management system. The respondents agreed to the fact that carbon accounting as a climate-change issue were fully incorporated into accounting and reporting systems of there companies. One objective of seeking such information is to assist managers formalize a corporate climate change strategy. This is because companies need information that potentially can be used as primary analytical tools related to market share, cost competitors and sales volume (Honggowati et al., 2017).

The study also showed that implementing the carbon management system brings about environmental effectiveness and economic efficiency. Asmeri et al. (2017) showed that CSR and CSR reporting are tools of legitimacy for companies to demonstrate their obedience, also that environmental performance has effect on CSR disclosure.

The study further showed that there is a strong and positive relationship between carbon accounting and return on equity of manufacturing firms. This is because Carbon Management System is a veritable tool for sustainable development. A number of companies see sustainable development as capable of offering a wide range of emerging business opportunities and as such are creating or redesigning their business models (Jones et al., 2017). The study showed that firms with a quality Carbon Management System in place achieve better carbon mitigation, because it can lead to both tangible and intangible outcomes.

\section{Conclusion}

The findings of the study are summarized as follows: 1) manufacturing firms are aware and disclose carbon related information, 2) accountants play a role in setting-up a corporate carbon management system in manufacturing firms, 3) there is a positive and statistically significant relationship between corporate carbon emissions and disclosure and corporate financial performance of manufacturing firms.

Carbon cost management is a subset of the drive toward "environmental cost accounting" that highlights the cost impacts beyond those related to a specific cost object, such as a product. Carbon management accounting is one part of sustainability accounting designed to provide managers with information that will assist companies facing short and long-term decisions about carbon emission issues in a world where company activities are strongly implicated in the related ecological crisis. These are inevitable challenges to traditional accounting methodology because carbon accounting also covers non-financial (socalled 'narrative') disclosure of corporate climate impact and carbon benchmarking. This study was aimed at providing empirical evidence on the role of carbon accounting in corporate carbon management systems in Nigeria. The results show a positive relationship between carbon accounting and performance. 
Based on the findings of this study, the following recommendations are here given: 1) adaptation to conditions that include long-term changing dynamics of the natural environment should be encouraged and the focus of finance and accounting system should not only cover short-term outcomes and management of short-term costing, reporting and disclosure but also long-term climate risks, 2) following the lack of research with a carbon accounting focus and scant evidence on efforts required and expended by accountants in that regard, Carbon management system should receive considerable attention of academic researches studies of empirical nature, 3 ) in addition to penalty for carbon emission, stronger penalty for failure to disclose carbon emission information should be employed.

\section{References}

Asmeri, R., Alvionita, T., \& Gunardi, A. (2017). CSR Disclosures in the Mining Industry: Empirical Evidence from Listed Mining Firms in Indonesia. Indonesian Journal of Sustainability Accounting and Management, 1(1), 1622. http://doi.org/10.28992/ijsam.v111.23

Bebbington, J., \& Larrinaga-González, C. (2008). Carbon Trading: Accounting and Reporting Issues. European Accounting Review, 17(4), 697-717. http://doi.org/10.1080/09638180802489162

Beck, A. C., Campbell, D., \& Shrives, P. J. (2010). Content Analysis in Environmental Reporting Research: Enrichment and Rehearsal of The Method in A British-German Context. The British Accounting Review, 42(3), 207-222. http://doi.org/10.1016/j.bar.2010.05.002

Boguski, T. K. (2010). Life Cycle Carbon Footprint of The National Geographic Magazine. The International Journal of Life Cycle Assessment, 15(7), 635-643. http://doi.org/10.1007/s11367-010-0210-5

Chapple, L., Clarkson, P. M., \& Gold, D. L. (2013). The Cost of Carbon: Capital Market Effects of the Proposed Emission Trading Scheme (ETS). Abacus, 49(1), 1-33. http://doi.org/10.1111/abac.12006

CIMA. (2010). Accounting for Climate Change. How Management Accountants Can Help Organizations Mitigate and Adapt to Climate Change. London: Chartered Institute of Management Accountants.

Cook, A. (2009). Emission Rights: From Costless Activity to Market Operations. Accounting, Organizations and Society, 34(3-4), 456-468. http://doi.org/10.1016/j.aos.2007.12.001

Finkbeiner, M. (2009). Carbon Footprinting-Opportunities and Threats. The International Journal of Life Cycle Assessment, 14(2), 91-94. http://doi.org/10.1007/s11367-009-0064-x

Giddens, A. (2009). The Politics of Climate Change. Cambridge.

Gunardi, A., Febrian, E., \& Herwany, A. (2016). The implication of firm-specific characteristics on disclosure: the case of Indonesia. International Journal of Monetary Economics and Finance, 9(4), 379-387. http://doi.org/10.1504/IJMEF.2016.080080

Hartmann, F., Perego, P., \& Young, A. (2013). Carbon Accounting: Challenges for Research in Management Control and Performance Measurement. Abacus, 49(4), 539-563. http://doi.org/10.1111/abac.12018

He, Y., Tang, Q., \& Wang, K. (2013). Carbon Disclosure, Carbon Performance, and Cost of Capital. China Journal of Accounting Studies, 1(3-4), 190-220. http://doi.org/10.1080/21697221.2014.855976

Hoffman, A. J. (2011a). Talking Past Each Other? Cultural Framing of Skeptical and Convinced Logics in the Climate Change Debate. Organization and Environment, 24(1), 3-33. http://doi.org/10.1177/1086026611404336

Hoffman, A. J. (2011b). The Culture and Discourse of Climate Skepticism. Strategic Organization, 9(1), 77-84. http://doi.org/10.1177/1476127010395065

Hoffmann, V. H., Sprengel, D. C., Ziegler, A., Kolb, M., \& Abegg, B. (2009). Determinants of Corporate Adaptation to Climate Change in Winter Tourism: An Econometric Analysis. Global Environmental Change, 19(2), 256-264. http://doi.org/10.1016/j.gloenvcha.2008.12.002 
Honggowati, S., Rahmawati, R., Aryani, Y. A., \& Probohudono, A. N. (2017). Corporate Governance and Strategic Management Accounting Disclosure. Indonesian Journal of Sustainability Accounting and Management, 1(1), 23-30. http://doi.org/10.28992/ijsam.v1i1.24

Hopwood, A. G. (2009). Accounting and The Environment. Accounting, Organizations and Society, 34(3-4), 433439. http://doi.org/10.1016/j.aos.2009.03.002

Hutcheson, G. D. (2011). Ordinary Least-Squares Regression. In The SAGE Dictionary of Quantitative Management Research (pp. 225-228). London: SAGE Publications Ltd. http://doi.org/10.4135/9781446251119.n67

IETA. (2007). Trouble-Entry Accounting - Revisited*. Uncertainty in accounting for the EU Emissions Trading Scheme and Certified Emission Reductions. London: PricewaterhouseCoopers.

IPCC. (2012). Managing the Risks of Extreme Events and Disaster to Advance Climate Change Adaptation. Special Report of the Intergovernmental Panel on Climate Change. Cambridge: Cambridge University Press.

IPCC. (2014). Climate Change 2014: Impacts, Adaptation, and Vulnerability. Summaries, Frequently Asked Questions, and Cross-Chapter Boxes. A Contribution of Working Group II to the Fifth Assessment Report of the Intergovernmental Panel on Climate Change.

Jeswani, H. K., Wehrmeyer, W., \& Mulugetta, Y. (2008). How Warm Is the Corporate Response to Climate Change? Evidence from Pakistan and the UK. Business Strategy and the Environment, 17(1), 46-60. http://doi.org/10.1002/bse.569

Jide, A. M. (2010). The Structure of the Nigerian Manufacturing Industry. In National Workshop on Strengthening Innovation and Capacity Building in the Nigerian Manufacturing Sector. National Office for Technology Acquisition and Promotion.

Jones, P., Wynn, M., Hillier, D., \& Comfort, D. (2017). The Sustainable Development Goals and Information and Communication Technologies. Indonesian Journal of Sustainability Accounting and Management, 1(1), 1-15. http://doi.org/10.28992/ijsam.v1i1.22

Khoiruman, M., \& Haryanto, A. T. (2017). Green Purchasing Behavior Analysis of Government Policy About Paid Plastic Bags. Indonesian Journal of Sustainability Accounting and Management, 1(1), 31-39. http://doi.org/10.28992/ijsam.v1i1.25

Kolk, A., Levy, D., \& Pinkse, J. (2008). Corporate Responses in an Emerging Climate Regime: The Institutionalization and Commensuration of Carbon Disclosure. European Accounting Review, 17(4), 719745. http://doi.org/10.1080/09638180802489121

Levy, D. L., \& Egan, D. (2003). A Neo-Gramscian Approach to Corporate Political Strategy: Conflict and Accommodation in the Climate Change Negotiations. Journal of Management Studies, 40(4), 803-829. http://doi.org/10.1111/1467-6486.00361

Linnenluecke, M., \& Griffiths, A. (2010). Beyond Adaptation: Resilience for Business in Light of Climate Change and Weather Extremes. Business \& Society, 49(3), 477-511. http://doi.org/10.1177/0007650310368814

Linnenluecke, M. K., Birt, J., \& Griffiths, A. (2015). The Role of Accounting in Supporting Adaptation to Climate Change. Accounting and Finance, 55(3), 607-625. http://doi.org/10.1111/acfi.12120

Linnenluecke, M. K., Griffiths, A., \& Winn, M. I. (2013). Firm and Industry Adaptation to Climate Change: A Review of Climate Adaptation Studies in The Business and Management Field. Wiley Interdisciplinary Reviews: Climate Change, 4(5), 397-416. http://doi.org/10.1002/wcc.214

Lohmann, L. (2009). Toward A Different Debate in Environmental Accounting: The Cases of Carbon and CostBenefit. Accounting, Organizations and Society, 34(3-4), 499-534. http://doi.org/10.1016/j.aos.2008.03.002 Lovell, H., \& MacKenzie, D. (2011). Accounting for Carbon: The Role of Accounting Professional Organisations in Governing Climate Change. Antipode, 43(3), 704-730. http://doi.org/10.1111/j.1467-8330.2011.00883.x

Matsumura, E. M., Prakash, R., \& Vera-Muñoz, S. C. (2014). Firm-Value Effects of Carbon Emissions and Carbon Disclosures. The Accounting Review, 89(2), 695-724. http://doi.org/10.2308/accr-50629 
McKinnon, A. C. (2010). Product-Level Carbon Auditing of Supply Chains: Environmental Imperative or Wasteful Distraction? International Journal of Physical Distribution and Logistics Management, 40(1/2), 42-60. http://doi.org/10.1108/09600031011018037

Munasinghe, M. (2010). Can Sustainable Consumers and Producers Save the Planet? Journal of Industrial Ecology, 14(1), 4-6. http://doi.org/10.1111/j.1530-9290.2009.00215.x

Okereke, C. (2007). An Exploration of Motivations, Drivers and Barriers to Carbon Management: The UK FTSE 100. European Management Journal, 25(6), 475-486. http://doi.org/10.1016/j.emj.2007.08.002

Olson, E. G. (2010). Challenges and Opportunities from Greenhouse Gas Emissions Reporting and Independent Auditing. Managerial Auditing Journal, 25(9), 934-942. http://doi.org/10.1108/02686901011080071

PricewaterhouseCoopers. (2009). Carbon Disclosure Project 2009 Global 500 Report. London.

Ratnatunga, J. (2007). Carbon Cost Accounting: The Impact of Global Warming on the Cost Accounting Profession. Journal of Applied Management Accounting Research, 5(2), 1-8.

Ratnatunga, J. (2008). Carbonomics: Strategic Management Accounting Issues. Journal of Applied Management Accounting Research, 6(1), 1-10.

Ratnatunga, J., Jones, S., \& Balachandran, K. R. (2011). The Valuation and Reporting of Organizational Capability in Carbon Emissions Management. Accounting Horizons, 25(1), 127-147. http://doi.org/10.2308/acch.2011.25.1.127

Ratnatunga, J. T. D., \& Balachandran, K. R. (2009). Carbon Business Accounting: The Impact of Global Warming on the Cost and Management Accounting Profession. Journal of Accounting, Auditing and Finance, 24(2), 333-355. http://doi.org/10.1177/0148558X0902400208

Reid, E. M., \& Toffel, M. W. (2009). Responding to Public and Private Politics: Corporate Disclosure of Climate Change Strategies. Strategic Management Journal, 30(11), 1157-1178. http://doi.org/10.1002/smj.796

Rokhmawati, A., \& Gunardi, A. (2017). Is going green good for profit? Empirical evidence from listed manufacturing firms in Indonesia. International Journal of Energy Economics and Policy, 7(4), 181-192.

Rokhmawati, A., Gunardi, A., \& Rossi, M. (2017). How Powerful is Your Customers' Reaction to Carbon Performance? Linking Carbon and Firm Financial Performance. International Journal of Energy Economics and Policy, 7(6), 85-95.

Romi, A. M. (2014). The Cost of Carbon: Capital Market Effects of the Proposed Emission Trading Scheme (ETS). Social and Environmental Accountability Journal, 34(1), 54-56. http://doi.org/10.1080/0969160X.2014.885191

Simnett, R., Nugent, M., \& Huggins, A. L. (2009). Developing an International Assurance Standard on Greenhouse Gas Statements. Accounting Horizons, 23(4), 347-363. http://doi.org/10.2308/acch.2009.23.4.347

Smith, M. (2003). Research Methods in Accounting. London: SAGE Publications, Ltd. http://doi.org/10.4135/9781849209809

Stechemesser, K., \& Guenther, E. (2012). Carbon Accounting: A Systematic Literature Review. Journal of Cleaner Production, 36, 17-38. http://doi.org/10.1016/j.jclepro.2012.02.021

Surminski, S. (2013). Private-Sector Adaptation to Climate Risk. Nature Climate Change, 3(11), 943-945. http://doi.org/10.1038/nclimate2040

Tang, Q., \& Luo, L. (2014). Carbon Management Systems and Carbon Mitigation. Australian Accounting Review, 24(1), 84-98. http://doi.org/10.1111/auar.12010

Weekes, P. (2007, April 8). Firms Go It Alone on Carbon Trading. The Sunday Age, p. 17.

West, J., \& Brereton, D. (2013). Climate Change Adaptation in Industry and Business: A Framework for Best Practice in Financial Risk Assessment, Governance and Disclosure. Gold Coast. 
Young, A. (2010). Greenhouse Gas Accounting: Global Problem, National Policy, Local Fugitives. Sustainability Accounting, Management and Policy Journal, 1(1), 89-95. http://doi.org/10.1108/20408021011059269

Zvezdov, D., \& Schaltegger, S. (2015). Decision Support Through Carbon Management Accounting-A Framework-Based Literature Review. In Corporate Carbon and Climate Accounting (pp. 27-44). Springer International Publishing. http://doi.org/10.1007/978-3-319-27718-9_2

\section{Appendix}

\section{Appendix: Questionnaire}

\section{Section A: Respondents Data}

Please tick $(\checkmark)$ in the appropriate boxes provided

Name of Organization:

1. Sex:

Male

Female

2. Years of Experience:

$0-5$ years

6-10 years

11-15 years

16 years and above

3. Management Level:

Top level management ( $\quad$ )

Mid-level management ( )

Key:

$\mathrm{SA}=$ Strongly Agree; $\mathrm{A}$ = Agree; $\mathrm{D}$ = Disagree; $\mathrm{SD}$ = Strongly Disagree; UD = Undecided

Section B: To what extent are manufacturing firms aware and disclose carbon related information?

\begin{tabular}{|c|c|c|c|c|c|c|}
\hline SN & Items/Suggestions & SA & $A$ & UD & $\mathrm{D}$ & SD \\
\hline 1. & $\begin{array}{l}\text { There is a global mandatory compliance on Carbon Management System to ease the } \\
\text { effect of climate change }\end{array}$ & & & & & \\
\hline 2. & $\begin{array}{l}\text { My firm has totally complied to this mandate and promotes disclosure of carbon emission } \\
\text { and setting up of carbon management system }\end{array}$ & & & & & \\
\hline 3. & $\begin{array}{l}\text { Carbon Accounting as a climate-change issues has been fully incorporated into } \\
\text { accounting and reporting. }\end{array}$ & & & & & \\
\hline 4. & $\begin{array}{l}\text { Carbon related information have received attention to research and development in my } \\
\text { company }\end{array}$ & & & & & \\
\hline 5. & $\begin{array}{l}\text { The Board of Directors has taken carbon disclosure as an integral part of my company's } \\
\text { Annual report }\end{array}$ & & & & & \\
\hline
\end{tabular}


Section C: What role do accountants play in setting-up a corporate carbon management system in manufacturing firms?

\begin{tabular}{|c|c|c|c|c|c|}
\hline SN & Items/Suggestions & SA $A$ & UD & $\mathrm{D}$ & SD \\
\hline 6. & $\begin{array}{l}\text { Accountants uses Carbon Disclosure Project reports to examine empirically the } \\
\text { implementation of systems by firms and evaluate firms true carbon performance }\end{array}$ & & & & \\
\hline 7. & $\begin{array}{l}\text { An objectives of carbon accounting is to assist managers to formalize climate change } \\
\text { strategy }\end{array}$ & & & & \\
\hline 8. & $\begin{array}{l}\text { Carbon Management System brings about environmental effectiveness and economic } \\
\text { efficiency }\end{array}$ & & & & \\
\hline 9. & $\begin{array}{l}\text { Firms with higher quality Carbon Management System have achieved better carbon } \\
\text { mitigation. }\end{array}$ & & & & \\
\hline 10. & $\begin{array}{l}\text { Better performance in carbon management can lead to both tangible and intangible } \\
\text { outcomes, such as lessen the financial burden and even bring profit for the company that } \\
\text { does well }\end{array}$ & & & & \\
\hline
\end{tabular}

